\title{
EVALUATION OF THE ANTINEOPLASTIC ACTIVITY OF L-RHAMNOSE IN VITRO. A COMPARISON WITH 2-DEOXYGLUCOSE
}

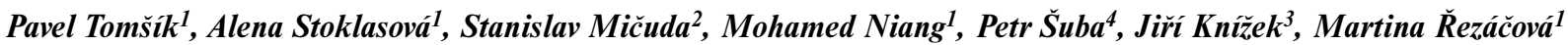

Charles University in Prague, Faculty of Medicine and University Hospital Hradec Králové, Czech Republic: Department of Biochemistry ${ }^{1}$, Department of Pharmacology ${ }^{2}$, Department of Medical Biophysics ${ }^{3}$, Department of Neurosurgery ${ }^{4}$

\begin{abstract}
Summary: The effect of unsubstituted deoxyhexoses, 2-deoxy-D-glucose (2-DG) and L-fucose, on tumor cells has been reported in several papers throughout the last decades. That of a similar deoxysugar, L-rhamnose, which is synthesized in bacteria and plants but not in animal cells, has until today not been explored. In the present study, we examined the effect of L-rhamnose on DNA and protein synthesis, growth and the potential induction of apoptosis of tumor cells in vitro. Using 2-DG for comparison, we studied the effect of L-rhamnose in concentrations up to 20 ( 32 resp.) $\mathrm{mmol} / \mathrm{l}$ on the initial velocity of the incorporation of labeled precursors of DNA and proteins in short term cultures of both mouse Ehrlich ascites tumor (EAT) and human HL-60 cells in vitro, and further, on cell proliferation and apoptosis induction in HL-60 cells. Neither cytotoxic nor cytostatic effects of L-rhamnose were observed with the exception of slightly pronounced inhibition of DNA synthesis in EAT cells. From the lacking inhibition of the protein synthesis it can be considered that L-rhamnose does not interfere with energy metabolism, at least not in a similar manner as 2-DG.
\end{abstract}

Key words: L-rhamnose; 2-deoxyglucose; DNA synthesis; Protein synthesis; Apoptosis; Tumor

\section{Introduction}

In the last decades, the possible effects of unsubstituted deoxyhexoses on tumor cells and their use in cancer treatment have been discussed. Above all, 2-deoxy-D-glucose (2DG) and L-fucose have been studied in numerous works both in vitro and in vivo. 2-Deoxyglucose is a synthetic glucose analogue that inhibits phospho-hexose isomerase in the initial stage of glycolysis $(29,33)$ and induces glucoseregulated stress affecting tumor cells in particular $(9,42)$. The inhibitory effect of 2-DG on tumor growth has been reported in both in vitro $(43)$ and in vivo $(5,10)$ studies. Glycolysis inhibition and resulting energy depletion trigger apoptotic cell death. The mechanisms include inhibition of phosphatidylinositol 3-kinase/Akt signaling (35), increased production of reactive oxygen species, interference with MAPK pathways and stabilization of p53 (19). Corresponding to this, 2-DG was found to induce cell death by the activation of apoptosis (1). Regardless of the mechanism which triggers apoptosis by either intrinsic (mitochondrial) or extrinsic (receptor) pathways, the apoptotic cells can be recognized by specific morphological changes: membrane blebbing, condensation, fragmentation of nuclear DNA, cleavage of nuclear proteins (e.g. lamin B) and formation of apoptotic bodies.

L-fucose (6-deoxy-L-galactose) is the only endogenous deoxyhexose known in humans. Although a research group reported the effect of intravenously administered L-fucose on the size of a rat solid mammary adenocarcinoma in vivo $(25,41)$ as well as the efficacy of this deoxysugar in vitro $(21,24,28,40)$, no significant cytostatic potency of single L-fucose in vitro or L-fucose monotherapy has been confirmed in the recent literature. However, it has been noted that L-fucose enhances the cytolytic activity of immune system effector cells and the production of cytokines like interleukin 2 and tumor necrosis factor $\alpha$ (30). It is well documented that altered fucosylation plays an important role in the pathogenesis of malignant tumors $(3,11,12)$. A potential antimetastatic effect of L-fucose and L-fucose containing oligosaccharides was reported as well (26).

In nature, there is another deoxyhexose - L-rhamnose (6-deoxy-L-mannose) - similar to deoxyglucose. It is synthesized largely in plants and bacteria but not in animal cells (7). Since L-rhamnose can serve as substrate for L-fucose kinase (8), which catalyzes the first step in the salvage pathway for GDP-fucose biosynthesis (3), a hypothesis can be formulated that L-rhamnose could influence the fucosylation and thereby the behavior of tumor cells. The fact that L-rhamnose can be converted into glycosides in mammalian cells has been indeed evidenced by sporadic discoveries of rhamnosides in mammals $(14,34)$. Moreover, L-rhamnose, which penetrates by non-mediated diffusion into the cells (4), may be partially metabolized or join some human metabolic pathways $(6,13)$. Although some synthetic ana- 
logues of L-rhamnose with significant cytostatic potency have been described $(16,20)$, the possible effect of L-rhamnose itself on tumor cell viability and proliferation has hitherto not been elucidated.

As the first step to evaluate the potential of L-rhamnose in cancer treatment, we examined the effect of L-rhamnose on DNA and protein synthesis, growth and the potential induction of apoptosis of tumor cells in vitro. Using 2-DG for comparison, we studied the effect of Lrhamnose on the initial velocity of the incorporation of labeled precursors of DNA and proteins in short term cultures of both mouse Ehrlich ascites tumor (EAT) and human HL-60 cells in vitro, and further, on cell proliferation and apoptosis induction in HL-60 cells.

\section{Material and Methods}

\section{Tumor cell lines}

The ascitic Ehrlich mammary adenocarcinoma was maintained and propagated in NMRI mice (Konárovice breeding farm, Czech Republic) at 10-day intervals by intraperitoneal (i. p.) transplantations of $10^{6}$ tumour cells. The care and handling of mice conformed to European Union recommendations on the handling of experimental animals.

The human promyelocyte leukemia cells HL-60 from the European Collection of Animal Cell Cultures (Porton Down, Salisbury, UK) were cultured in Iscove's modified Dulbecco's medium (Sigma-Aldrich Co, St. Louis, MO, USA) supplemented with a $20 \%$ fetal calf serum in a humidified incubator at $37{ }^{\circ} \mathrm{C}$ and a controlled $5 \% \mathrm{CO}_{2}$ atmosphere. The cultures were divided every $2^{\text {nd }}$ day by a dilution to a concentration of $2 \times 10^{5}$ cells $/ \mathrm{ml}$. The cell counts were performed with a hemocytometer, the cell membrane integrity was determined by using the Trypan blue exclusion technique. The cell lines in the maximal range of up to 20 passages were used for this study.

\section{In vitro DNA and protein synthesis assay}

The mouse EAT cells were obtained from the peritoneal cavity on day 7 after i. p. inoculation of $10^{6}$ tumour cells in female NMRI mice. Cell suspensions were packed by lowspeed centrifugation $\left(600 \mathrm{x} \mathrm{g}\right.$ for $10 \mathrm{~min}$ at $\left.4{ }^{\circ} \mathrm{C}\right)$. The cells were resuspended in Krebs III phosphate buffer (all components obtained from Sigma-Aldrich Co.), $\mathrm{pH}$ 7.4, without calcium but enriched with D-glucose $(540 \mathrm{mg} / \mathrm{l})$ and ascitic plasma $(2.5 \%, \mathrm{v} / \mathrm{v})$. The cell suspensions were incubated for $150 \mathrm{~min}$ at $37{ }^{\circ} \mathrm{C}$ with the addition of $\left[6{ }^{3} \mathrm{H}\right]$ thymidine (70 $\mathrm{kBq} / \mathrm{ml}$ of incubated suspension) and L-[U- $\left.{ }^{14} \mathrm{C}\right]$-amino acid mixture $(10 \mathrm{kBq} / \mathrm{ml}$ of incubated suspension) obtained from Lacomed s.r.o., Czech Republic and 2-DG or L-rhamnose (Sigma-Aldrich Co.). The cell density was $1.5 \times 10^{6} / \mathrm{ml}$ cells $/ \mathrm{ml}$ incubated suspension. Samples were taken at $30 \mathrm{~min}$ intervals from 0 to $180 \mathrm{~min}$ and processed by the method of Mattern using filter paper discs (17). The activities of 5\% trichloracetic acid-insoluble fractions were measured by liquid scintillation spectrometry (Triton scintillation fluid, Chemopetrol, Czech Rep.) and liquid scintillation counter Beckman LS6000 LL (Beckman Coulter, Inc., CA, USA). For the calculation of the initial velocity of precursors incorporation $\left(v_{0}\right)$, the eq. [1] was used:

$$
\ln \left(\frac{I_{t}-I_{0}}{t I_{\max }}\right)=\ln (A)-B t
$$

where $I_{t}$ and $I_{o}$ are the activities of acid-insoluble fractions of $0.075 \mathrm{ml}$ suspension samples taken at time $t$ and 0 , respectively. $I_{\max }$ is the total (both acid-soluble and acid-insoluble) activity in $0.075 \mathrm{ml}$ of the particular cell suspension. The empirical constant $A$ is directly proportional to the rate of macromolecular biosynthesis; the constant $B$ depends on the degradation of the acid-insoluble fraction (18). For the calculation of $I C_{50}$ value, which is the concentration of inhibitor at which the initial velocity is $50 \%$ of that of the uninfluenced control, linear regression of the dependence of $v_{0}$ on the logarithm of the inhibitor concentration, i.e. $v_{0}=a+b \times \log c$, was performed. The software MS Excel 2003 a NCSS was used for the calculations and statistical evaluations.

\section{Cell cycle analysis}

Following the incubation, the cells were washed with cold PBS, fixed by $70 \%$ ethanol and stained with propidium iodide (PI) in Vindelov's solution for 30 minutes at $37{ }^{\circ} \mathrm{C}$. Fluorescence (DNA content) was measured with Coulter Electronic (Hialeah, FL, USA) apparatus. A minimum of 5000 cells analyzed in each sample served to determine the percentages of cells in each phase of the cell cycle using Multicycle AV software.

\section{Lamin B cleavage}

At various times after treatment, the HL-60 cells were washed with a PBS. The lysates containing an equal amount of protein $(30 \mu \mathrm{g})$ were loaded into each lane of a SDS polyacrylamide gel. After electrophoresis, the proteins were transferred to a PVDF membrane. The membranes were blocked in TRIS-buffered saline containing $0.05 \%$ Tween 20 and $5 \%$ non-fat dry milk and then incubated with a primary antibody (Oncogene, Cambridge, MA, USA) at $4{ }^{\circ} \mathrm{C}$ overnight. After washing, the blots were incubated with a secondary antibody (Dako, High Wycombe, UK) and the signal was developed with a chemiluminiscence (ECL) detection kit (Boehringer Mannheim, Germany).

\section{Results}

\section{DNA and protein biosynthesis}

In EAT cells, the incorporation of both $\left[6-{ }^{3} \mathrm{H}\right]$-thymidine and $\mathrm{L}-\left[\mathrm{U}-{ }^{14} \mathrm{C}\right]$-amino acid mixture was significantly decreased when incubated with 2-DG (Tab. 1). The $I C_{50}$ values accounted for 1.87 and $3.64 \mathrm{mmol} / 1$, respectively. In 
HL-60 cells, only the incorporation of $\left[6-{ }^{3} \mathrm{H}\right]$-thymidine was altered by $2-\mathrm{DG}$ with the $I C_{50}$ of $19.31 \mathrm{mmol} / 1$. The incorporation of labeled amino acids remained uninfluenced. It was found by testing that the slope $b$ of "linear dependence of the incorporation initial velocity on the concentration logarithm" is practically equal to zero, so we can state that the incorporation initial velocity $v_{0}$ is practically independent of the inhibitor concentration.

In the presence of L-rhamnose, merely a slight inhibition of the $\left[6-{ }^{3} \mathrm{H}\right]$-thymidine incorporation rate in EAT cells was observed (at $20 \mathrm{mmol} / 1,68.4 \%$ of the control) (Tab. 1) but no significant inhibition in HL-60 cells (also

Tab. 1: Evaluation of the kinetics of $\left[6-{ }^{3} \mathrm{H}\right]$-thymidine* ${ }^{*}$ and $\mathrm{L}-\left[\mathrm{U}-{ }^{14} \mathrm{C}\right]$-amino acid mixture ${ }^{\dagger}$ incorporation into EAT cells in the presence of 2-DG or L-rhamnose.

\begin{tabular}{|c|c|c|c|c|c|c|}
\hline $\mathrm{c}(\mathrm{mmol} / \mathrm{l})$ & $\mathrm{A}^{*}$ & $\mathrm{~B}^{*}$ & $\mathrm{v}_{0}{ }^{*}$ & $\mathrm{~A}^{\dagger}$ & $\mathrm{B}^{\dagger}$ & $\mathrm{v}_{0}^{\dagger}$ \\
\hline 0 & 0.0201 & 0.0058 & 16.3 & 0.00136 & 0.0092 & 0.637 \\
\hline 0 & 0.0177 & 0.0047 & 15.4 & 0.00130 & 0.0081 & 0.596 \\
\hline 0 & 0.0187 & 0.0051 & 14.5 & 0.00135 & 0.0087 & 0.645 \\
\hline \multicolumn{7}{|l|}{ 2-DG } \\
\hline 0.3125 & 0.0162 & 0.0039 & 12.8 & 0.00110 & 0.0075 & 0.519 \\
\hline 0.3125 & 0.0151 & 0.0036 & 12.3 & 0.00113 & 0.0075 & 0.539 \\
\hline 1.25 & 0.0156 & 0.004 & 11.8 & 0.00114 & 0.0076 & 0.524 \\
\hline 1.25 & 0.0142 & 0.0033 & 10.7 & 0.00120 & 0.0074 & 0.545 \\
\hline 5 & 0.00374 & 0.0024 & 2.86 & 0.000666 & 0.0044 & 0.315 \\
\hline 5 & 0.00293 & 0.0017 & 2.27 & 0.000456 & 0.001 & 0.207 \\
\hline 20 & 0.000819 & 0.0024 & 0.634 & 0.000235 & 0.0043 & 0.106 \\
\hline 20 & 0.00113 & 0.0023 & 0.836 & 0.000192 & 0.0022 & 0.088 \\
\hline \multicolumn{7}{|l|}{ L-Rhamnose } \\
\hline 0.3125 & 0.0170 & 0.0041 & 13.6 & 0.00125 & 0.0077 & 0.576 \\
\hline 0.3125 & 0.0166 & 0.0041 & 14.0 & 0.00115 & 0.0074 & 0.554 \\
\hline 1.25 & 0.0161 & 0.004 & 13.2 & 0.00121 & 0.0078 & 0.550 \\
\hline 1.25 & 0.0166 & 0.0041 & 13.2 & 0.00118 & 0.0075 & 0.559 \\
\hline 5 & 0.0152 & 0.0037 & 12.0 & 0.00123 & 0.0085 & 0.577 \\
\hline 5 & 0.0144 & 0.0026 & 11.1 & 0.00118 & 0.0072 & 0.534 \\
\hline 20 & 0.0143 & 0.0027 & 10.7 & 0.00126 & 0.0079 & 0.548 \\
\hline 20 & 0.0131 & 0.0027 & 10.4 & 0.00130 & 0.0089 & 0.596 \\
\hline
\end{tabular}

Empirical constants $A, B$ from the eq. [1], initial velocities of the process $\left(\mathrm{v}_{0}\right)\left[\mathrm{s}^{-1}\right]$.

\section{A 2-DG}

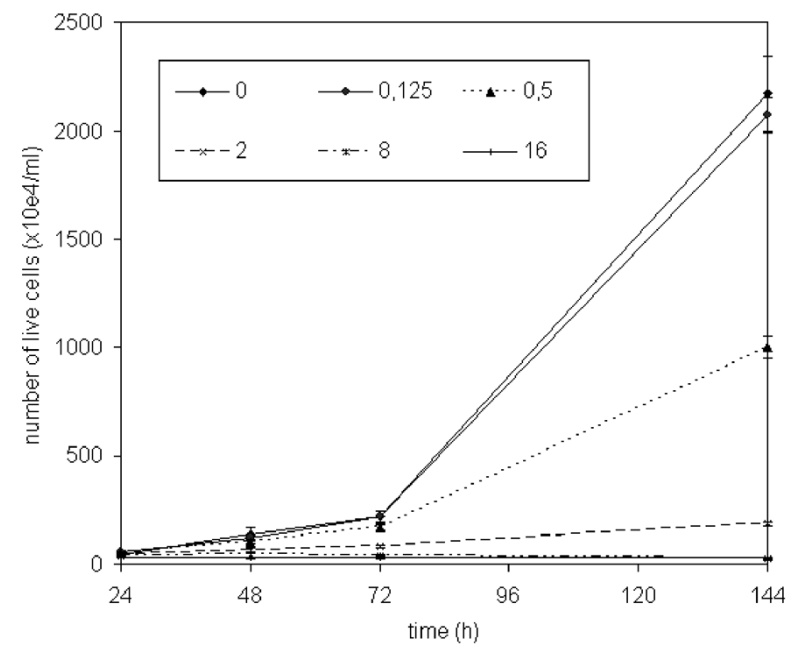

B L-Rhamnose

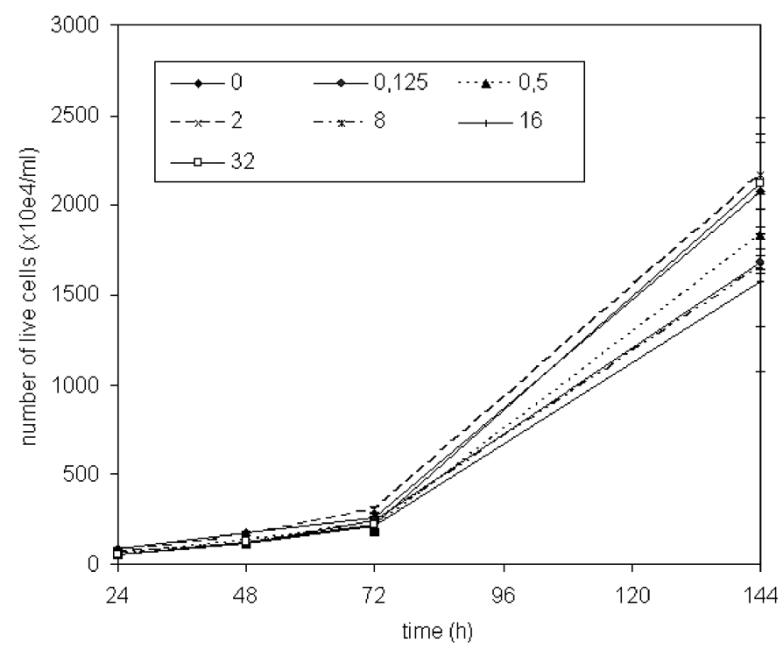

Fig. 1: Effect of L-rhamnose and 2-deoxyglucose on proliferation of HL-60 cells.

HL-60 cells were exposed to L-rhamnose or 2-deoxyglucose in final concentration from $0,125 \mathrm{mmol} / 1$ to 32 or $16 \mathrm{mmol} / 1$, resp., in full cultivating medium. The data represent mean values from three experiments \pm standard deviation. 

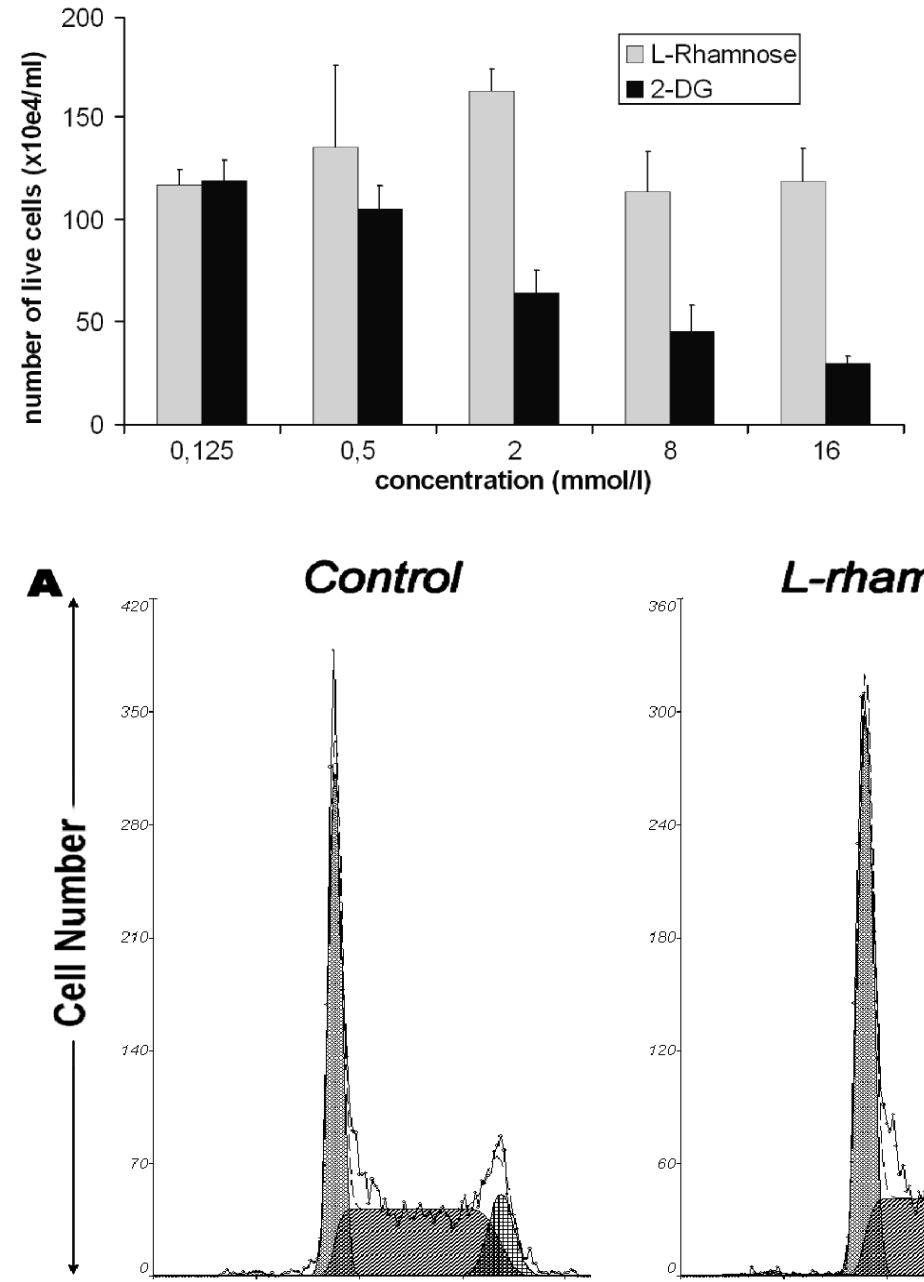

B

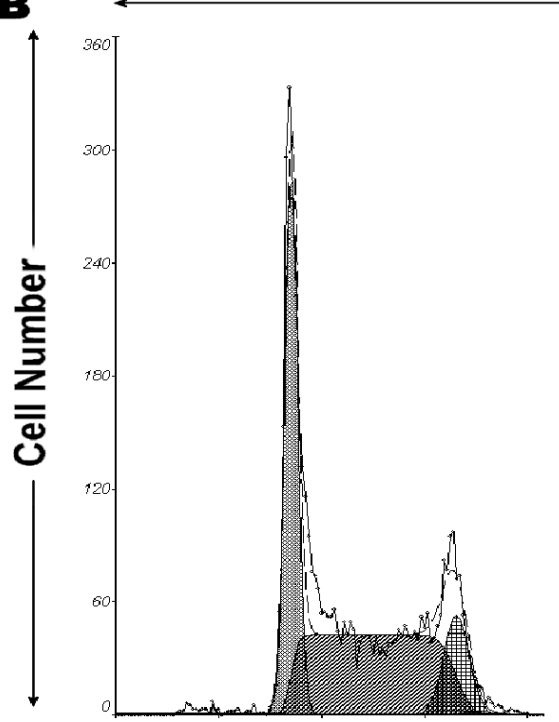

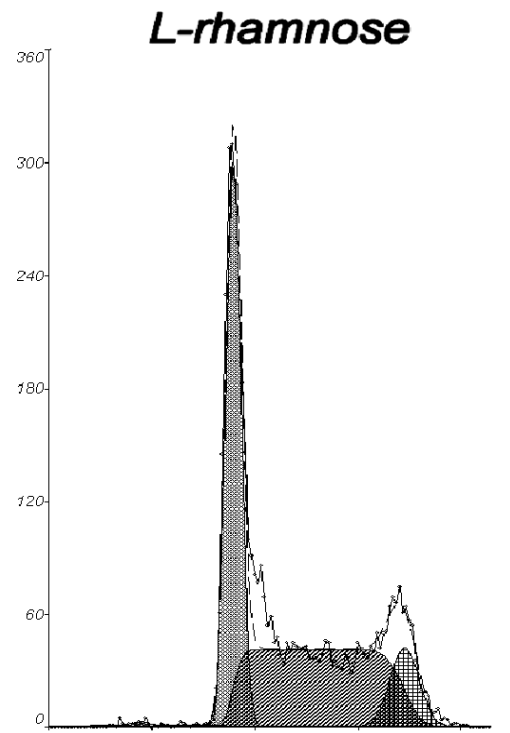
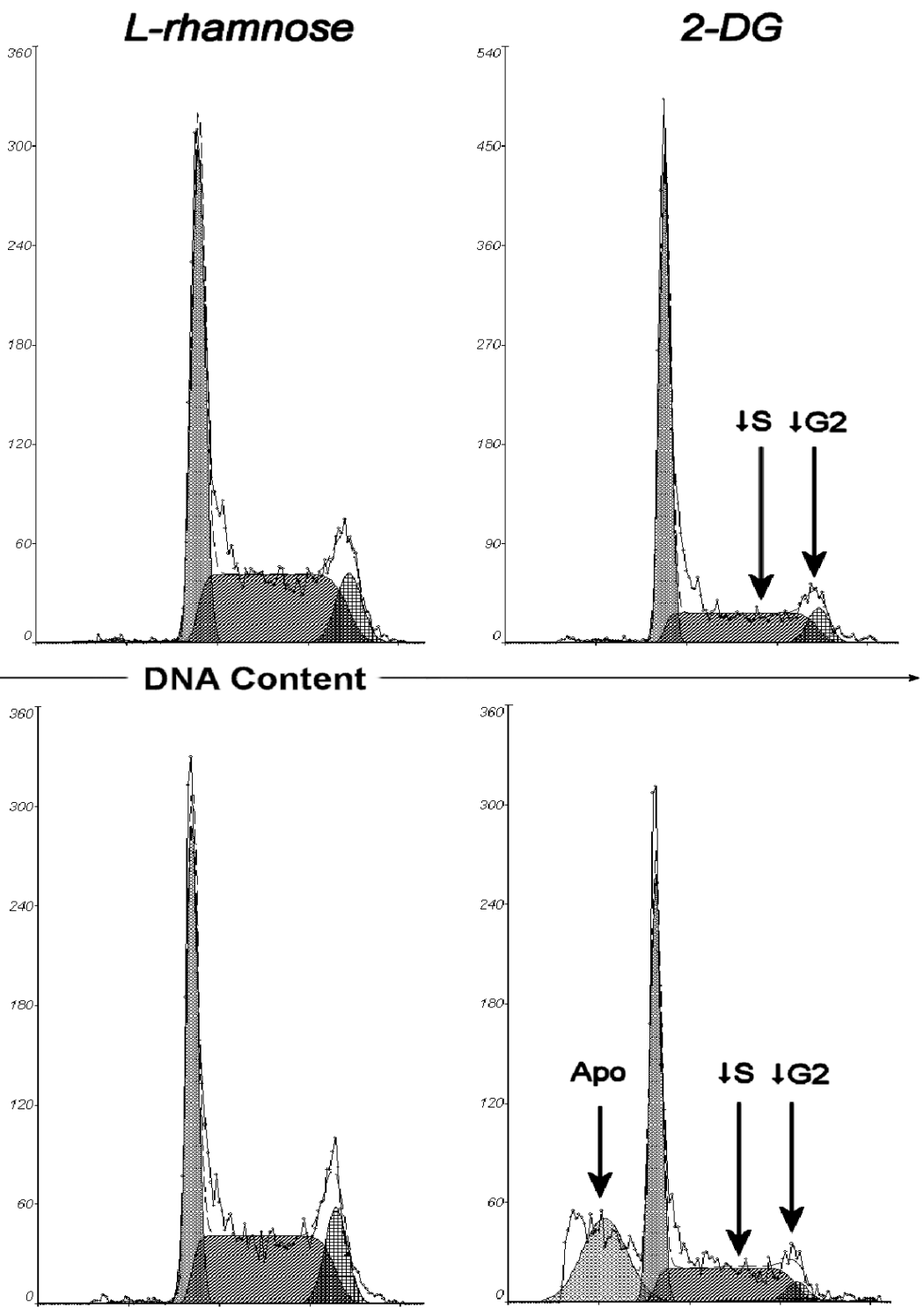

Fig. 3: Effect of L-rhamnose and 2-deoxyglucose on cell cycle distribution and apoptosis induction.

HL-60 cells were exposed to $5 \mathrm{mmol} / 1$ L-rhamnose or 2-deoxyglucose for $24 \mathrm{~h} \mathrm{(A)}$ or $72 \mathrm{~h}(\mathrm{~B})$ and DNA content in each cell was measured by flowcytometry. 2-DG induced cell cycle arrest in G1 phase and consecutive apoptosis. Apoptosis was detected as subG1 peak, i. e. the cells with lower content of DNA than normal cells in G1 phase. 
here the slope $b$ was found practically equal to zero; see above). Analogically, no significant alteration of L-[U- $\left.{ }^{14} \mathrm{C}\right]$ amino acid mixture incorportion in the presence of L-rhamnose was noted.

\section{Cell growth}

At the beginning of the experiment, HL-60 cells were diluted to a concentration of $2 \times 10^{5} / \mathrm{ml}$. Exponential growth of control cells was apparent during the observation interval (Fig. 1). 2-DG in a concentration of $0.5 \mathrm{mmol} / 1$ caused a decrease of proliferation (analyzed as the number of viable cells) in comparison with the control cells. 2-DG in concentrations 2-16 mmol/1 completely inhibited proliferation of HL-60 cells (Fig. 1A). When L-rhamnose was applied to the culture medium in concentrations of $0.125-32$ $\mathrm{mmol} / 1$, no significant difference in the number of viable cells was observed compared to the control cells (Fig. 1B). The inhibition of proliferation by 2-DG is concentration-dependent (Fig. 2) and can be seen in cells exposed to 2-DG in concentrations of $0.5 \mathrm{mmol} / 1$ or higher from $48 \mathrm{~h}$ of incubation onwards.

\section{Cell cycle and apoptosis}

After exposure to $5 \mathrm{mmol} / 12-\mathrm{DG}$ the cells undergo cell cycle arrest in the $\mathrm{G} 1 / \mathrm{S}$ phase $24 \mathrm{~h}$ after the beginning of the treatment. The percentage of cells in S and G2/M phase decreases from $50 \%(\mathrm{~S}), 2 \%(\mathrm{G} 2 / \mathrm{M})$ in control cells to $38 \%(\mathrm{~S}), 8 \%(\mathrm{G} 2 / \mathrm{M})$ in $2-\mathrm{DG}$ treated cells. At later intervals, $72 \mathrm{~h}$ after the beginning of the 2-DG treatment, a subG1 peak representing apoptotic cells is detected (29\% of cells) (Fig. 3A). During apoptosis, nuclear DNA is specifically cleaved in internucleosomal sequences and small DNA fragments are produced. These fragments then leave the cells and thus apoptotic cells have a lower content of DNA then the cells in the G1 phase of the cell cycle. L-Rhamnose in the same concentration $(5 \mathrm{mmol} / \mathrm{l})$ does not affect distribution of the cells in cell cycle phases and does not induce apoptosis (Fig. 3B).

This observation was confirmed by detection of small fragments of lamin B. This fragment is produced by caspase cleavage of $68 \mathrm{kDa}$ molecule of nuclear protein lamin $\mathrm{B}$.

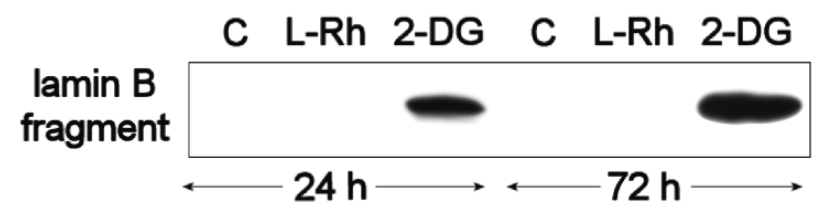

Fig. 4: Effect of L-rhamnose and 2-deoxyglucose on lamin B cleavage.

HL-60 cells were exposed to $5 \mathrm{mmol} / 1 \mathrm{~L}$-rhamnose or 2-deoxyglucose for $24 \mathrm{~h}$ (A) or $72 \mathrm{~h}$ (B), lysed, and fragments of lamin B detected in whole cell lysates by western blotting. 2-DG induces strong fragmentation of lamin B, indicating caspase activity and apoptosis in treated cells, while L-rhamnose does not.
Fragments of lamin B were detected after both 24 and 72 hlong incubation of HL-60 cells with 2-DG, but they were not present after incubation with L-rhamnose (Fig. 4).

\section{Discussion}

In the present study, we compared the antitumor effect of two deoxyhexoses, 2-deoxy-D-glucose and L-rhamnose on both mouse EAT and human HL-60 tumor cell lines. Whereas 2-DG decreased the initial rate of DNA synthesis in both EAT and HL-60, as well as that of protein synthesis in EAT, L-rhamnose showed only a weak inhibition of the DNA synthesis and no significant influence on protein synthesis. We have shown in this study that 2-DG decreases proliferation, arrests cell cycles in $\mathrm{G} 1$ phase and induces apoptosis in human promyelocytic leukemia cells HL-60, while L-rhamnose has no effect on these processes.

The initial velocities of DNA and protein synthesis are two closely related markers of cell proliferation. As Müller et al. (22) showed for EAT cells, protein synthesis is an extremely energy demanding process. Thus, 2-DG which reduces the ATP production in tumor cells $(9,42)$ was therefore expected to inhibit the protein synthesis. Our results confirm this assumption. In contrast to 2-DG, L-rhamnose did not affect the protein synthesis and acted several times weaker on the DNA synthesis in EAT. This might be understood as an indication that L-rhamnose does not interfere with the energy metabolism, at least not in a similar manner as 2-DG. Nevertheless, the mechanism of the slight alteration of the DNA synthesis in EAT in the presence of L-rhamnose is not clear. In HL-60 cells the inhibition of DNA synthesis by 2-DG, is relatively inferior, which may be due to the absence of p53 (39). The influence of the tested deoxysugars on protein synthesis in HL-60 was not evaluated because of abundant concentrations of amino acids in the medium necessary for the cell growth.

The applied method of dynamic monitoring of specific activities of NA and protein fractions has significant advantages when compared to conventional incorporation assays. The conventional assays for nucleic acids and/or protein synthesis measure only one point of the time-incorporation curve, while our dynamic monitoring allows for observing the kinetics of precursor incorporation. In addition, if a particular functional dependence is detected, even hardly assessable data having a high variance can be evaluated. The equation [1] is based on the theoretical concept of a homogeneous material flow with simultaneous isotope turnover according to the model of Neyman $(18,23)$. This equation represents a solution of differential equations describing a steady state of the observed process in a closed system, where the analytical concentrations of both the macromolecules and their precursors do not vary within the incubation time. From the derivation of eq. [1] it follows that only the initial incorporation velocity is proportional to the biosynthesis rate. Initial incorporation velocity is directly proportional to the empirical constant $A$ : 


$$
v_{0}=v_{t=0}=\left(\frac{\partial I_{t}}{\partial t}\right)_{t=0}=\left[A I_{\max } e^{-B t}(1-B t)\right]_{t=0}=A I_{\max }
$$

Although the use of a mixture of amino acids may complicate the solution of kinetic relations, it can be considered to be more accurate compared to the use of a single amino acid (23).

We have shown that 2-DG decreases proliferation and induces apoptosis in human promyelocytic leukemia cells HL-60 as determined by flow-cytometric analysis of cell DNA content, as well as by lamin B cleavage. 2-DG in concentrations of $5 \mathrm{mmol} / 1$ first (after $24 \mathrm{~h}$ ) inhibits proliferation of the cells and induces changes in cell cycle: an increase of the number of cells in G1 phase, accompanied by a decrease in the number of cells in $\mathrm{S}$ and $\mathrm{G} 2 / \mathrm{M}$ phase. This is followed by the occurrence of cells with a subG1 amount of DNA, i.e. apoptotic cells, $72 \mathrm{~h}$ after the beginning of exposure to 2-DG. It was reported by many studies that p53 lacking cells, including HL-60 cells, react to DNAdamaging factors (such as e.g. ionizing radiation or topoisomerase II inhibitors) preferentially by arrest of cell cycle in $\mathrm{G} 2 / \mathrm{M}$ phase, which is followed by apoptosis induction $(2,15,27,31,32,36-38)$. This was not observed after 2-DG treatment, indicating that direct damage to DNA is not responsible for the antitumor effect of 2-DG. This corresponds with findings of Aft et al. (1) and with the proposed mechanism of the antitumor effect of 2-DG: glycolysis inhibition and resulting energy depletion. This inference is also supported by the fact that the constant $B$ [1], which indicates DNA degradation does not increase with increases in 2-DG concentration, as shown in Tab. 1. Neither inhibition of proliferation, cell cycle changes, nor induction of apoptosis were observed after treatment of HL-60 cells with L-rhamnose.

Thus, it can be concluded that L-rhamnose in concentration up to 20 (32 resp.) $\mathrm{mmol} / 1$ can not be considered as cytotoxic or cytostatic for the used in vitro tumor models and it may act differently than 2-DG. Nevertheless, the hypothetical analogy of L-rhamnose to L-fucose in the influence on the behavior of tumor cells in vivo may retain, the unexplored potential of L-rhamnose, which awaits future clarification.

\section{Acknowledgement}

We acknowledge the skilful technical assistance of Eva Vodáková. This study was supported by project grant No. MSM 0021620820, Ministry of Education, Czech Republic.

\section{References}

1. Aft RL, Zhang FW, Gius D. Evaluation of 2-deoxy-D-glucose as a chemotherapeutic agent: mechanism of cell death. Br J Cancer. 2002;87:805-12.

2. Bache M, Pigorsch S, Dunst J, Wurl P, Meye A, Barte F, Schmidt H, Rath FW, Taubert H. Loss of G2/M arrest correlates with radiosensitization in two human sarcoma cell lines with mutant p53. Int J Cancer 2001;96:110-117.

3. Becker DJ, Lowe JB. Fucose: biosynthesis and biological function in mammals. Glycobiology 2003; 13:41R-53R.
4. Bjarnason I, Macpherson A, Hollander D. Intestinal permeability: an overview. Gastroenterology 1995;108:1566-81.

5. Cay O, Radnell M, Jeppsson B, Ahrn B, Bengmark S. Inhibitory effect of 2-deoxyD-glucose on liver tumor growth in rats. Cancer Res 1992;52:5794-6.

6. Cuatrecasas P, Segal S. Mammalian galactose dehydrogenase. II. Properties, substrate specificity, and developmental changes. J Biol Chem 1966;241:5910-8.

7. Giraud MF, Naismith JH. The rhamnose pathway. Curr Opin Struct Biol 2000;10:687-96

8. Ishihara H, Massaro DJ, Heath EC. The metabolism of L-fucose. 3. The enzymatic synthesis of beta-L-fucose 1-phosphate. J Biol Chem 1968;243:1103-9.

9. Karczmar GS, Arbeit JM, Toy BJ, Speder A, Weiner MW. Selective depletion of tumor ATP by 2-deoxyglucose and insulin, detected by 31P magnetic resonance spectroscopy. Cancer Res 1992;52:71-6

10. Kern KA, Norton JA. Inhibition of established rat fibrosarcoma growth by the glucose antagonist 2-deoxy-D-glucose. Surgery 1987;102(2):380-5

11. Kim YJ, Varki A. Perspectives on the significance of altered glycosylation of glycoproteins in cancer. Glycoconj J 1997:14:569-76.

12. Kossowska B, Ferens-Sieczkowska M, Gancarz R, Passowicz-Muszyska E, Jankowska R. Fucosylation of serum glycoproteins in lung cancer patients. Clin Chem Lab Med 2005;43:361-9

13. Malagon I, Onkenhout W, Klok M, van der Poel PF, Bovill JG, Hazekamp MG. Rhamnose and rhamnitol in dual sugar permeability tests. J Pediatr Gastroenterol Nutr 2006;43:265-6.

14. Malawista I, Davidson EA. Isolation and identification of rhamnose from rabbit skin. Nature 1961;192:871-2

15. Mareková M, Vávrová J, Vokurková D. Dose dependent biological effects of idarubicin in HL-60 cells: alterations of the cell-cycle and apoptosis. Acta Medica (Hradec Kralove) 2000;43:69-73.

16. Martin A, Butters TD, Fleet GWJ. A highly cytotoxic L-rhamnose analogue of the antitumour agent spicamycin. Chem Commun 1998;19:2119-2120

17. Mattern J, Kaufmann M, Wayss K, Volm M: Studies on the Drug Sensitivity of Short Term Cultivated Tumour Cell Suspensions. „Human Tumours in Short Term Culture“ (red. Dendy PP), p. 301. London, New York, San Francisco, Academic Press 1976

18. Mělka M. Průběh inkorporace směsi L- $\left[\mathrm{U}-{ }^{14} \mathrm{C}\right]$ aminokyselin in vitro v závislost na koncentraci buněk Ehrlichova ascitického karcinomu. Rigorózní práce. Př́rodovědecká fakulta University Karlovy v Praze. Praha 1980.

19. Moley KH, Mueckler MM. Glucose transport and apoptosis. Apoptosis 2000 5:99-105.

20. Mons S, GWJ, An approach to the generation of simple analogues of the antitumour agent spicamycin. Org Biomol Chem 2003, 1: 3685-3691

21. Mullen JL, Rosato FE, Allen TR, Miller EE, Roseman J, Rosato EF. Continuous intravenous fucose therapy in rat mammary cancer II. J Surg Oncol 1973;5:6-9.

22. Mller M, Buttgereit F, Dumdey R, Rapoport SM. Quantification of ATP-producing and consuming processes of Ehrlich ascites tumour cells. Eur J Biochem 1986;161:701-5.

23. Nejman MB, Gal D. Primenenije radioaktivnych izotopov v chimiceskoj kinetike. Moskva, Nauka 1970

24. Rosato FE, Mullen JL, Rosato EF, Steiger E, Miller EE. Continuous intravenous fucose treatment of rat mammary tumor. J Surg Oncol 1972:4:94-101

25. Roseman JM, Miller EE, Seltzer MH, Wolfe D, Rosato FE. The effect of L-fucose on rat mammary tumor growth II. In vitro studies. J Surg Oncol 1971;3:79-88.

26. Roszkowski W, Beuth J, Ko HL, Uhlenbruck G, Pulverer G. Blocking of lectinlike adhesion molecules on pulmonary cells inhibits lung sarcoma L-1 colonization in BALB/c-mice. Experientia. 1989;45:584-8.

27. Schafer, J., Bachtler, J., Engling, A., Little, J. B., Weber, K. J., Wenz, F.: Suppression of apoptosis and clonogenic survival in irradiated human lymphoblasts with different TP53 status. Radiat Res 2002;158: 699-706.

28. Seltzer MH, Roseman JM, Wolfe DE, Tsou KC, Miller EE, Rosato FE. The ef fects of L-fucose on rat mammary tumor growth. Growth 1969;33: 353-359.

29. Sols A, Crane RK. Substrate specificity of brain hexokinase. J Biol Chem 1954;210:581-595.

30. Staňková J. Fucose-activated killer cells. I. Enhanced TNF- $\alpha$ mRNA accumulation and protein production. J Leukoc Biol 1992;52: 188-196.

31. Szumiel I, Kapiszewska M, John A, Gradska I, Kowalczyk D, Janik P. Caffeineinhibitable control of the radiation-induced G2 arrest in L5178Y-S cells deficient in non-homologous end-joining: Radiat. Environ. Biophys 2001;40:137-143.

32. Theron T, Binder A, Verheye-Dua F, Bohm L. The role of G2-block abrogation, DNA double-strand break repair and apoptosis in the radiosensitization of melanoma and squamous cell carcinoma cell lines by pentoxifylline. Int $\mathbf{J}$ Radiat Biol 2000;76:1197-1208.

33. Tower DB. The effects of 2-deoxy-D-glucose on metabolism of slices of cerebral cortex incubated in vitro. J Neurochem 1958;3: 185-205.

34. Tymiak AA, Norman JA, Bolgar M, DiDonato GC, Lee MH, Parker WL, Lo LC, Berova N, Nakanishi K, Haber E. Physicochemical characterization of a ouabain isomer isolated from bovine hypothalamus. Proc Natl Acad Sci U.S.A. 1993; 90:8189-93.

35. Tzatsos A, Tsichlis PN. Energy Depletion Inhibits Phosphatidylinositol 3-K nase/Akt Signaling and Induces Apoptosis via AMP-activated Protein Kinase-dependent Phosphorylation of IRS-1 at Ser-794. J Biol Chem 2007;282:18069-82. 
36. Vávrová J, Mareková M, Vokurková D, Psutka J. Cell cycle alteration and response to low-dose-rate gamma radiation in leukemic cell lines. Physiol Res 2004; $53: 335-342$.

37. Vávrová J, Mareková M, Vokurková D, Szkanderová S, Psutka J. Caffeine induce a second wave of apoptosis after low dose-rate gamma radiation of HL-60 cells. Radiat Environ Biophys 2003;42:193-199.

38. Vávrová J, Řezáčová M, Vokurková D, Östereicher J, Vilasová Z. Degradace Cdc25A fosfatasy $\mathrm{v}$ odpovědi na poškození buněk HL-60 ionizujícím zářením. Radiační Onkologie 2004, 86-89.

39. Wolf D, Rotter V. Major deletions in the gene encoding the p53 tumor antigen cause lack of p53 expression in HL-60 cells. Proc Natl Acad Sci U S A. 1985; 82:790-4.
40. Wolfe D, Roseman JM, Miller E, Seltzer MH, Rosato FE. The effect of L-fucose on rat mammary tumor growth I. In vivo Studies. J Surg Oncol 1971:3:73-77.

41. Wolfe DE, Roseman JM, Seltzer MH, Miller FE, Rosato FE. Further observations of L-fucose as a specific inhibitor of rat mammary carcinoma in tissue culture. Growth 1970;34:379-384.

42. Yamada M, Tomida A, Yun J, Cai B, Yoshikawa H, Taketani Y, Tsuruo T Cellular sensitization to cisplatin and carboplatin with decreased removal of platinumDNA adduct by glucose-regulated stress. Cancer Chemother Pharmacol 1999;44: 59-64.

43. Zhu Z, Jiang W, McGinley JN, Thompson HJ. 2-Deoxyglucose as an energy restriction mimetic agent: Effects on mammary carcinogenesis and on mammary tumor cell growth in vitro. Cancer Res 2005;65:7023-30.

Submitted May 2008. Accepted June 2008.

\section{Corresponding author:}

Pavel Tomšík, M.D., Department of Biochemistry, Charles University in Prague, Faculty of Medicine in Hradec Králové, Šimkova 870, 50038 Hradec Králové, Czech Republic, e-mail: tomsikp@lfhk.cuni.cz 